\title{
IMPLEMENTASI PERATURAN MENTERI PENDIDIKAN DAN KEBUDAYAAN NOMOR 103 TAHUN 2014 TERHADAP RENCANA PEMBELAJARAN GURU
}

\author{
Oleh \\ Muawanah \\ punyamuawanah@gmail.com
}

\begin{abstract}
Purposes of applying the regulation of the minister of education and culture number 103 in 2014 to manufacture the implementation plan for the implementation of learning is learning more focused and to the achievement of learning objectives. Lesson plan (RPP) is one manifestation of the curriculum development shall be prepared by the teacher and used as guidance in implementing the learning. Efforts towards the implementation of the regulation of the minister of education and culture number 103 in 2014 against the lesson plan teachers through on going guidance, training, and on the job training to teachers. Here we describe how the implementation of the regulation of the minister of education and culture number 103 in 2014 against the lesson plan teachers. The method used in this paper is descriptive qualitative research method literature study. For schools and school principals in order to spruce up the administration of teacher learning device. For teachers to be able to implement the regulation of the minister of education and culture number 103 in 2014 to plan the implementation of learning as feedback in order to understand the performance and the factors that influence so as to stimulate the teachers efforts to improve its capabilities.
\end{abstract}

Keywords: Regulation of the minister of education and culture number 103 in 2014, Lesson Plan, Teachers

\section{Pendahuluan}

Pendidikan merupakan investasi dalam pengembangan sumber daya manusia dan dipandang sebagai kebutuhan dasar bagi masyarakat yang ingin maju. Komponen-komponen sistem pendidikan yang mencakup sumber daya manusia dapat digolongkan menjadi dua yaitu: tenaga kependidikan guru dan non guru. Menurut Undang-Undang Nomor 20 tahun 2003 tentang Sistem Pendidikan Nasional menyatakan, "komponen-komponen sistem pendidikan yang bersifat sumber daya manusia dapat digolongkan menjadi tenaga pendidik dan pengelola satuan pendidikan (penilik, pengawas, peneliti dan pengembang pendidikan)" (Depdiknas, 2003: 5). Tenaga gurulah yang mendapatkan perhatian lebih banyak di antara komponen-komponen sistem pendidikan. Besarnya 
perhatian terhadap guru antara lain dapat dilihat dari banyaknya kebijakan khusus seperti kenaikan tunjangan fungsional guru dan sertifikasi guru.

Usaha-usaha untuk mempersiapkan guru menjadi profesional telah banyak dilakukan. Kenyataan menunjukkan bahwa tidak semua guru memiliki kinerja yang baik dalam melaksanakan tugasnya. Hal itu ditunjukkan dengan kenyataan: (1) guru sering mengeluh kurikulum yang berubah-ubah, (2) guru sering mengeluhkan kurikulum yang syarat dengan beban, (3) seringnya siswa mengeluh dengan cara mengajar guru yang kurang menarik, dan (4) masih belum dapat dijaminnya kualitas pendidikan sebagaimana mestinya.

Berdasarkan kenyataan begitu berat dan kompleksnya tugas serta peran guru tersebut, perlu diadakan supervisi atau pembinaan terhadap guru secara terus menerus untuk meningkatkan kinerjanya. Kinerja guru perlu ditingkatkan agar usaha membimbing siswa untuk belajar dapat berkembang. Menurut Pidarta (1992: 54) bahwa proses pengembangan kinerja guru terbentuk dan terjadi dalam kegiatan belajar mengajar di tempat guru bekerja. Selain itu kinerja guru dipengaruhi oleh hasil pembinaan dan supervisi kepala sekolah atau pengawas sekolah.

Pada pelaksanaan Kurikulum 2013 menuntut kemampuan baru pada guru untuk dapat mengelola proses pembelajaran secara efektif dan efisien. Tingkat produktivitas sekolah dalam memberikan pelayanan-pelayanan secara efisien kepada pengguna (peserta didik, masyarakat) akan sangat tergantung pada kualitas guru yang terlibat langsung dalam proses pembelajaran dan keefektifan guru dalam melaksanakan tanggung jawab individual dan kelompok. Hal ini berarti bahwa guru sebagai fasilitator yang mengelola proses pembelajaran di kelas mempunyai andil dalam menentukan kualitas pendidikan. Konsekuensinya adalah guru harus mempersiapkan atau merencanakan semua kebutuhan perangkat pembelajaran agar proses pembelajaran di kelas berjalan dengan efektif.

\section{Peraturan Menteri Pendidikan dan Kebudayaan Nomor 103 Tahun 2014}

Selanjutnya diterbitkan Permendikbud nomor 103 tahun 2014 tentang Pedoman Pelaksanaan Pembelajaran (Depdiknas, 2014:3). Permendikbud itu 
merupakan pedoman pelaksanaan pembelajaran untuk jenjang SD, SMP/MTs dan SMA/MA/SMK. Salah satu isi permendikbud nomor 103/2014 adalah format RPP. Dikeluarkannya Permendikbud ini adalah digunakan sebagai pedoman dalam pelaksanaan Pembelajaran bagi guru di jenjang pendidikan dasar sampai menengah. Pelaksanaan pembelajaran yang dimaksud meliputi perencanaan pembelajaran, proses pembelajaran, dan evaluasi pembelajaran.

RPP disusun oleh guru dengan mengacu pada silabus dengan prinsip: (a) memuat secara utuh kompetensi dasar sikap spiritual, sikap sosial, pengetahuan, dan keterampilan; (b) dapat dilaksanakan dalam satu atau lebih dari satu kali pertemuan; (c) memperhatikan perbedaan individual peserta didik; (d) berpusat pada peserta didik; (e) berbasis konteks; (f) berorientasi kekinian; (g) mengembangkan kemandirian belajar; (h) memberikan umpan balik dan tindak lanjut pembelajaran; (i) memiliki keterkaitan dan keterpaduan antarkompetensi dan/atau antarmuatan; dan (j) memanfaatkan teknologi informasi dan komunikasi. Prinsip RPP diwujudkan dalam bentuk pembelajaran reguler, pengayaan, dan remedial. RPP paling sedikit memuat: (a) identitas sekolah/madrasah, mata pelajaran atau tema, kelas/semester, dan alokasi waktu; (b) kompetensi inti, kompetensi dasar, dan indikator pencapaian kompetensi; (c) materi pembelajaran; (d) kegiatan pembelajaran yang meliputi kegiatan pendahuluan, kegiatan inti, dan kegiatan penutup; (e) penilaian, pembelajaran remedial, dan pengayaan; dan (f) media, alat, bahan, dan sumber belajar.

\section{Guru}

Guru Secara etimologi (asal usul kata), istilah "Guru" berasal dari bahasa India yang artinya "orang yang mengajarkan tentang kelepasan dari sengsara" Shambuan, Republika, (dalam Suparlan 2005: 11). Kemudian Rabindranath Tagore (dalam Suparlan 2005: 11) menggunakan istilah Shanti Niketan atau rumah damai untuk tempat para guru mengamalkan tugas mulianya membangun spiritualitas anak-anak bangsa di India (spiritual intelligence). 
Pengertian guru kemudian menjadi semakin luas, tidak hanya terbatas dalam kegiatan keilmuan yang bersifat kecerdasan spiritual (spiritual intelligence) dan kecerdasan intelektual (intellectual intelligence), tetapi juga menyangkut kecerdasan kinestetik jasmaniah (bodily kinesthetic), seperti guru tari, guru olah raga, guru senam dan guru musik. Dengan demikian, guru dapat diartikan sebagai orang yang tugasnya terkait dengan upaya mencerdaskan kehidupan bangsa dalam semua aspeknya, baik spiritual dan emosional, intelektual, fisikal, maupun aspek lainnya.

Poerwadarminta (dalam Suparlan 2005: 13) menyatakan, "guru adalah orang yang kerjanya mengajar". Dengan definisi ini, guru disamakan dengan pengajar. Pengertian guru ini hanya menyebutkan satu sisi yaitu sebagai pengajar, tidak termasuk pengertian guru sebagai pendidik dan pelatih. Selanjutnya Zakiyah Daradjat (dalam Suparlan 2005: 13) menyatakan, "guru adalah pendidik profesional karena guru telah menerima dan memikul beban dari orang tua untuk ikut mendidik anak-anak".

UU Guru dan Dosen Republik Indonesia Nomor 14 Tahun 2005, "Guru adalah pendidik profesional dengan tugas utama mendidik, mengajar, membimbing, mengarahkan, melatih, menilai, dan mengevaluasi peserta didik pada pendidikan anak usia dini jalur pendidikan formal, pendidikan dasar, dan pendidikan menengah". Selanjutnya UU No. 20 Tahun 2003 pasal 39 ayat 2 tentang Sistem Pendidikan Nasional menyatakan "pendidik merupakan tenaga professional yang bertugas merencanakan dan melaksanakan proses pembelajaran, menilai hasil pembelajaran, melakukan pembimbingan dan pelatihan, serta melakukan penelitian dan pengabdian kepada masyarakat, terutama bagi pendidik pada perguruan tinggi" (Depdiknas, 2003: 19).

PP No. 19 Tahun 2005 tentang Standar Nasional Pendidikan menyatakan, “pendidik (guru) harus memiliki kualifikasi akademik dan kompetensi sebagai agen pembelajaran, sehat jasmani dan rohani, serta memiliki kemampuan untuk mewujudkan tujuan pendidikan nasional". Berdasarkan definisi di atas, dapat disimpulkan bahwa guru adalah tenaga pendidik yang profesional dengan tugas utama mendidik, mengajar, membimbing, mengarahkan, melatih, menilai dan 
mengevaluasi peserta didik, dan bertugas merencanakan dan melaksanakan proses pembelajaran.

\section{Standar Kompetensi Guru}

Depdiknas (2004: 4) kompetensi diartikan, "sebagai pengetahuan, keterampilan, dan nilai-nilai dasar yang direfleksikan dalam kebiasaan berpikir dan bertindak". Secara sederhana kompetensi diartikan seperangkat kemampuan yang meliputi pengetahuan, sikap, nilai dan keterampilan yang harus dikuasai dan dimiliki seseorang dalam rangka melaksanakan tugas pokok, fungsi dan tanggung jawab pekerjaan dan/atau jabatan yang disandangnya (Nana Sudjana 2009: 1).

Nurhadi (2004: 15) menyatakan, "kompetensi merupakan pengetahuan, keterampilan, dan nilai-nilai dasar yang direfleksikan dalam kebiasaan berpikir dan bertindak". Selanjutnya menurut para ahli pendidikan McAshan (dalam Nurhadi 2004: 16) menyatakan, "kompetensi diartikan Sebagai pengetahuan, keterampilan, dan kemampuan yang dikuasai seseorang sebagai pengetahuan". Keterampilan dan kemampuan yang dikuasai seseorang yang telah menjadi bagian dari dirinya, sehingga dapat melakukan perilaku-perilaku kognitif, afektif, dan psikomotor dengan sebaik-baiknya.

Kompetensi diartikan sebagai pengetahuan, keterampilan, dan nilai-nilai dasar yang direfleksikan dalam kebiasaan berfikir dan bertindak (Suparlan). Arti lain dari kompetensi adalah spesifikasi dari pengetahuan, keterampilan, dan sikap yang dimiliki seseorang serta penerapannya di dalam pekerjaan, sesuai dengan standar kinerja yang dibutuhkan oleh lapangan. Berdasarkan pendapat di atas dapat disimpulkan kompetensi adalah sebagai suatu kecakapan untuk melakukan sesuatu pekerjaan berkat pengetahuan, keterampilan ataupun keahlian yang dimiliki untuk melaksanakan suatu pekerjaan.

Undang-Undang Guru dan Dosan No.14 Tahun 2005 Pasal 8 menyatakan, "guru wajib memiliki kualifikasi akademik, kompetensi, sertifikat pendidik, sehat jasmani dan rohani, serta memiliki kemampuan untuk mewujudkan tujuan 37|Jurnal Vijjacariya Vol.3 Nomor 1 Tahun 2016 
pendidikan nasional". Dari rumusan tersebut jelas disebutkan pemilikan kompetensi oleh setiap guru merupakan syarat yang mutlak harus dipenuhi oleh guru. Dengan demikian, kompetensi yang dimiliki oleh setiap guru akan menunjukkan kualitas guru yang sebenarnya.

Selanjutnya Pasal 10 menyebutkan empat kompetensi yang harus dimiliki oleh guru yakni: (1) kompetensi pedagogik, (2) kompetensi kepribadian, (3) kompetensi sosial, dan (4) kompetensi professional. Kompetensi tersebut akan terwujud dalam bentuk penguasaan pengetahuan, keterampilan, maupun sikap profesional dalam menjalankan fungsi sebagai guru.

Berdasarkan beberapa definisi di atas dapat disimpulkan standar Kompetensi guru adalah suatu pernyataan tentang kriteria yang dipersyaratkan, ditetapkan dalam bentuk penguasaan perangkat kemampuan yang meliputi pengetahuan, sikap, nilai dan keterampilan bagi seorang tenaga kependidikan sehingga layak disebut kompeten. Standar kompetensi guru dipilah ke dalam tiga komponen yang saling terkait, yakni: (1) pengelolaan pembelajaran, (2) pengembangan profesi, dan (3) penguasaan akademik. Komponen pertama terdiri atas empat kompetensi, komponen kedua memiliki satu kompetensi, dan komponen ketiga memiliki dua kompetensi. Dengan demikian, ketiga komponen tersebut secara keseluruhan meliputi tujuh kompetensi dasar, yaitu: penyusunan rencana pembelajaran, (2) pelaksanaan interaksi belajar mengajar, (3) penilaian prestasi belajar peserta didik, (4) pelaksanaan tindak lanjut hasil penilaian prestasi belajar peserta didik, (5) pengembangan profesi, (6) pemahaman wawasan kependidikan, dan (7) penguasaan bahan kajian akademik (sesuai dengan mata pelajaran yang diajarkan).

Abdurrahman Mas'ud (dalam Suparlan 2005: 99) menyebutkan tiga kompetensi dasar yang harus dimiliki guru, yakni: (1) menguasai materi atau bahan ajar, (2) antusiasme, dan (3) penuh kasih sayang (loving) dalam mengajar dan mendidik.

\section{Tujuan dan Manfaat Standar Kompetensi Guru}

Depdiknas (2004: 4) tujuan adanya Standar Kompetensi Guru adalah sebagai jaminan dikuasainya tingkat kompetensi minimal oleh guru sehingga 38 IJurna 1 Vijjacariya Vo1.3 Nomor 1 Tah un 2016 
yang bersangkutan dapat melakukan tugasnya secara profesional, dapat dibina secara efektif dan efisien serta dapat melayani pihak yang berkepentingan terhadap proses pembelajaran, dengan sebaik-baiknya sesuai bidang tugasnya. Adapun manfaat disusunnya standar kompetensi guru adalah sebagai acuan pelaksanaan uji kompetensi, penyelenggaraan diklat, dan pembinaan, maupun acuan bagi pihak yang berkepentingan terhadap kompetensi guru untuk melakukan evaluasi, pengembangan bahan ajar dan sebagainya bagi tenaga kependidikan.

\section{Rencana Pelaksanaan Pembelajaran}

Perencanaan proses pembelajaran meliputi silabus dan rencana pelaksanaan pembelajaran yang terdiri dari rencana kegiatan mingguan (RKM) dan rencana kegiatan harian (RKH). Silabus merupakan sebagian sub-sistem pembelajaran yang terdiri dari satu sama lain yang saling berhubungan dalam rangka mencapai tujuan. Hal penting yang berkaitan dengan pembelajaran adalah penjabaran tujuan yang disusun berdasarkan indikator yang ditetapkan.

Philip Combs (dalam Kurniawati, 2009: 66) menyatakan bahwa perencanaan program pembelajaran merupakan suatu penetapan yang memuat komponen-komponen pembelajaran secara sistematis. Analisis sistematis merupakan proses perkembangan pendidikan yang akan mencapai tujuan pendidikan agar lebih efektif dan efisien disusun secara logis, rasional, sesuai dengan kebutuhan siswa, sekolah, dan daerah (masyarakat). Perencanaan program pembelajaran adalah hasil pemikiran, berupa keputusan yang akan dilaksanakan. Selanjutnya Oemar Hakim (dalam Kurniawati 2009: 74) menyatakan, "bahwa perencanaan program pembelajaran pada hakikatnya merupakan perencanaan program jangka pendek untuk memperkirakan suatu proyeksi tentang sesuatu yang akan dilakukan dalam kegiatan pembelajaran".

Permendiknas No. 41 Tahun 2007 menyatakan, "Rencana kegiatan harian (RKH) adalah rencana yang menggambarkan prosedur dan pengorganisasian 
pembelajaran untuk mencapai satu kompetensi dasar yang ditetapkan dalam standar isi dan telah dijabarkan dalam silabus".

Berdasarkan pendapat di atas dapat disimpulkan bahwa perencanaan pembelajaran adalah suatu upaya menyusun perencanaan pembelajaran yang akan dilaksanakan dalam kegiatan pembelajaran untuk mencapai tujuan yang telah ditetapkan dalam kurikulum sesuai dengan kebutuhan siswa, sekolah, dan daerah.

\section{Komponen Rencana Pelaksanaan Pembelajaran}

Menurut Permendiknas No. 41 Tahun 2007, komponen RKH terdiri dari: (a) identitas mata pelajaran, (b) standar kompetensi, (c) kompetensi dasar, (d) indikator pencapaian kompetensi, (e) tujuan pembelajaran, (f) materi ajar, (g) alokasi waktu, (h) metode pembelajaran, (i) kegiatan pembelajaran meliputi: pendahuluan, inti, penutup, (j) sumber belajar, (k) penilaian hasil belajar.

Peraturan Pemerintah Republik Indonesia No. 19 (2005 pasal 20) menyatakan bahwa, "RKH minimal memuat sekurang-kurangnya lima komponen yang meliputi: (1) tujuan pembelajaran, (2) materi ajar, (3) metode pengajaran, (4) sumber belajar, dan (5) penilaian hasil belajar."

\section{Prinsip-Prinsip Penyusunan RKH}

Permendiknas No. 41 Tahun 2007 menyatakan dalam menyusun rencana pelaksanaan pembelajaran harus memperhatikan prinsip-prinsip sebagai berikut: (a) memperhatikan perbedaan individu peserta didik, (b) mendorong partisipasi aktif peserta didik, (c) mengembangkan budaya membaca dan menulis, (d) memberikan umpan balik dan tindak lanjut, (e) keterkaitan dan keterpaduan.

\section{Langkah- langkah Menyusun RKH}

Langkah-langkah menyusun RKH adalah: (a) Mengisi kolom identitas, (b) Menentukan alokasi waktu yang dibutuhkan untuk pertemuan yang telah ditetapkan, (c) Menentukan SK, KD, dan indikator yang akan digunakan yang terdapat pada silabus yang telah disusun, (d) Merumuskan tujuan pembelajaran 
berdasarkan SK, KD dan indikator yang telah ditentukan, (e) mengidentifikasi materi ajar berdasarkan materi pokok/pembelajaran yang terdapat dalam silabus, materi ajar merupakan uraian dari materi pokok/pembelajaran, (f) menentukan metode pembelajaran yang akan digunakan, (g) merumuskan langkah-langkah yang terdiri dari kegiatan awal, inti dan akhir, (h) menentukan alat/bahan/sumber belajar yang digunakan, dan (i) menyusun kriteria penilaian, lembar pengamatan, contoh soal, teknik penskoran dan kunci jawaban.

\section{Hal-Hal yang Perlu Diperhatikan dalam Menyusun RKH}

Dalam penyusunan RKH perlu memperhatikan hal sebagai berikut: (a) $\mathrm{RKH}$ disusun untuk setiap KD yang dapat dilaksanakan dalam satu kali pertemuan atau lebih, (b) tujuan pembelajaran menggambarkan proses dan hasil belajar yang harus di capai oleh peserta didik sesuai dengan kompetenrsi dasar, (c) tujuan pembelajaran dapat mencakupi sejumlah indikator, atau satu tujuan pembelajaran untuk beberapa indikator, yang penting tujuan pembelajaran harus mengacu pada pencapaian indikator, (d) Kegiatan pembelajaran (langkahlangkah pembelajaran) dibuat setiap pertemuan, bila dalam satu RKH terdapat 3 kali pertemuan, maka dalam RKH tersebut terdapat 3 langkah pembelajaran, (e) Bila terdapat lebih dari satu pertemuan untuk indikator yang sama, tidak perlu dibuatkan langkah kegiatan yang lengkap untuk setiap pertemuannya.

\section{Pembahasan}

Perencanaan pembelajaran merupakan langkah yang sangat penting sebelum pelaksanaan pembelajaran. Perencanaan yang matang diperlukan supaya pelaksanaan pembelajaran berjalan secara efektif. Perencanaan Pembelajaran dituangkan ke dalam Rencana Kegiatan Mingguan (RKM) dan Rencana Kegiatan Harian (RKH) atau beberapa istilah lain seperti desain pembelajaran, dan skenario pembelajaran. RKM dan RKH memuat tingkat pencapaian perkembangan, indikator yang akan dicapai, materi yang akan 
dipelajari, metode pembelajaran, langkah pembelajaran, media pembelajaran, dan sumber belajar serta penilaian.

Silabus dan RPP dikembangkan oleh guru pada satuan pendidikan. Guru pada satuan pendidikan berkewajiban menyusun silabus dan RPP yang dituangkan dalam RKM dan RKH secara lengkap dan sistematis agar pembelajaran berlangsung secara interaktif, inspiratif, menyenangkan, menantang, memotivasi peserta didik untuk berpartisipasi aktif, serta memberikan ruang yang cukup bagi prakarsa, kreativitas, dan kemandirian sesuai dengan bakat, minat dan perkembangan fisik serta psikologis peserta didik.

Masalah yang terjadi di lapangan masih ditemukan adanya guru (baik di sekolah negeri maupun swasta) yang tidak bisa memperlihatkan RKM dan RKH yang dibuat dengan alasan ketinggalan di rumah dan bagi guru yang sudah membuat RKM dan RKH masih ditemukan adanya guru yang belum melengkapi komponen tujuan pembelajaran dan penilaian, serta langkahlangkah kegiatan pembelajarannya masih dangkal. Pada komponen penilaian (penskoran) sebagian besar guru tidak lengkap membuatnya dengan alasan sudah tahu dan ada di kepala.

Sedangkan pada komponen tujuan pembelajaran, materi ajar, metode pembelajaran, dan sumber belajar sebagian besar guru sudah membuatnya. Masalah yang lain yaitu sebagian besar guru khususnya di sekolah swasta belum mendapatkan pelatihan pengembangan RKH. Selama ini guru-guru yang mengajar di sekolah swasta sedikit/jarang mendapatkan kesempatan untuk mengikuti berbagai Diklat Peningkatan Profesionalisme Guru dibandingkan sekolah negeri. Hal ini menyebabkan banyak guru yang belum tahu dan memahami penyusunan/pembuatan RKH secara baik/lengkap. Beberapa guru mengadopsi RKH orang lain. Permasalahan tersebut berpengaruh besar terhadap pelaksanaan proses pembelajaran.

Rencana Program Pembelajaran harus dibuat agar kegiatan pembelajaran berjalan sistematis dan mencapai tujuan pembelajaran. Tanpa Rencana Program Pembelajaran, biasanya pembelajaran menjadi tidak terarah. Oleh karena itu, guru harus mampu menyusun RKM dan RKH dengan lengkap berdasarkan 42 | J u r n a 1 V i j j a c a riy a V o 1.3 Nom or 1 T a h u n 2016 
silabus yang disusunnya. Rencana Program Pembelajaran sangat penting bagi seorang guru karena merupakan acuan dalam melaksanakan proses pembelajaran.

Semua guru di setiap sekolah harus menyusun RPP. RPP yang telah disusun dianjurkan untuk dikembangkan dan dikonsultasikan kepada pengawas sekolah. Tujuannya agar penyusunan RPP berdasarkan Permendikbud 103 Tahun 2014 sesuai dengan kerangka yang telah diatur sebelumnya. Penyusunan RPP berdasarkan Permendikbud 103 Tahun 2014 harus disosialisasikan oleh Kementerian Pendidikan dan Kebudayaan kepada pengawas, kepala sekolah, dan guru. Sehingga pada akhirnya pengawas, kepala sekolah, dan guru akan memiliki kemampuan yang mumpuni dalam penyusunan RPP berdasarkan Permendikbud 103 Tahun 2014.

Namun realitanya masih banyak guru yang belum melaksanakan kewajibannya dalam menyusun RPP. Paling tidak terdapat tiga faktor yang dipandang sebagai penyebab guru belum melaksanakan kewajiban tersebut. Pertama, karena sudah terlalu lama menjadi "tukang mengajar" (kurikulum 1950-1994) sehingga belum tumbuhnya kesadaran bahwa menyusun RPP adalah kewajiban guru; kedua, karena belum dipahaminya makna sebuah RPP dalam Pembelajaran; dan ketiga dengan sistem rekrutmen guru dan sifat terbukanya profesi guru, bisa jadi sebagian guru belum memiliki kompetensi untuk menyusun RPP.

Oleh karena itu, perlu adanya upaya-upaya yang dilakukan untuk mengimplementasikan pembuatan RPP berdasarkan Permendikbud 103 Tahun 2014. Salah satunya dengan melalui cara bimbingan berkelanjutan. Frank Parson 1951 (dalam RM Fatihah http: //eko13.wordpress.com) menyatakan, "bimbingan sebagai bantuan yang diberikan kepada individu untuk dapat memilih, mempersiapkan diri dan memangku suatu jabatan dan mendapat kemajuan dalam jabatan yang dipilihnya". Chiskon 1959 (dalam RM Fatihah http: //eko13.wordpress.com) menyatakan, "bimbingan membantu individu untuk lebih mengenal berbagai informasi tentang dirinya sendiri". 
Berikutnya Bernard dan Fullmer 1969 (dalam RM Fatihah http: //eko13.wordpress.com) menyatakan, "bahwa bimbingan dilakukan untuk meningkatkan perwujudan diri individu". Dapat dipahami bahwa bimbingan membantu individu untuk mengaktualisasikan diri dengan lingkungannya. Menurut Tim Redaksi Kamus Besar Bahasa Indonesia, "bimbingan adalah petunjuk penjelasan cara mengerjakan sesuatu, tuntutan".

Dari beberapa pengertian bimbingan di atas, dapat ditarik kesimpulan bahwa bimbingan adalah pemberian bantuan kepada individu secara berkelanjutan dan sistematis yang dilakukan oleh seorang ahli yang telah mendapat latihan khusus untuk itu, dimaksudkan agar individu dapat memahami dirinya, lingkungannya, serta dapat mengarahkan diri dan menyesuaikan diri dengan lingkungan untuk dapat mengembangkan potensi dirinya secara optimal untuk kesejahteraan dirinya dan kesejahteraan masyarakat. Menurut Redaksi Kamus Besar Bahasa Indonesia, Edisi Kedua, "berkelanjutan adalah berlangsung terus menerus, berkesinambungan" (Tim Penyusun, 2015: 15).

Berdasarkan pengertian bimbingan dan berkelanjutan dapat ditarik suatu kesimpulan bahwa bimbingan berkelanjutan adalah pemberian bantuan yang diberikan seorang ahli kepada seseorang atau individu secara berkelanjutan berlangsung secara terus menerus untuk dapat mengembangkan potensi dirinya secara optimal dan mendapat kemajuan dalam bekerja.

Selain itu, ada upaya lain yang dilakukan untuk implementasi Permendikbud 103 tahun 2014 terhadap rencana pembelajaran guru, yakni sebagai berikut:

1. Training, yakni merupakan suatu program yang dilaksanakan karena diasumsikan dapat meningkatkan kemampuan para guru agar dapat melaksanakan tugasnya secara efektif dan efesien, salah satunya menyusun Rencana Pelaksanaan Pembelajaran (RPP); dan

2. On the job training adalah sebagai upaya pembekalan pengetahuan dan keterampilan bahkan sikap kepada para guru agar guru dapat melaksanakan pekerjaannya sesuai dengan bidang dan keahliannya masingmasing. 
Pada umumnya guru belum tahu kerangka penyusunan RKH, hanya sekolah yang memiliki dokumen standar proses, hanya beberapa orang guru yang pernah mengikuti pelatihan pengembangan $\mathrm{RKH}$ tetap belum bisa maksimal, umumnya guru mengadopsi dan mengadaptasi $\mathrm{RKH}$, kebanyakan guru tidak tahu dan tidak paham menyusun RKH secara lengkap, mereka setuju bahwa guru harus menggunakan $\mathrm{RKH}$ dalam melaksanakan proses pembelajaran yang dapat dijadikan acuan/pedoman dalam proses pembelajaran. Selain itu, kebanyakan guru belum tahu dengan komponen-komponen RKH secara lengkap.

Rencana Program Pembelajaran harus dibuat agar kegiatan pembelajaran berjalan sistematis dan mencapai tujuan pembelajaran. Tanpa Rencana Program Pembelajaran, biasanya pembelajaran menjadi tidak terarah. Oleh karena itu, guru harus mampu menyusun RKM dan $\mathrm{RKH}$ dengan lengkap berdasarkan silabus yang disusunnya. Rencana Program Pembelajaran sangat penting bagi seorang guru karena merupakan acuan dalam melaksanakan proses pembelajaran.

Dengan diberikannya bimbingan berkelanjutan, training, dan on the job training guru tersebut menunjukkan sikap yang baik dan termotivasi dalam menyusun RPP dengan lengkap. Sehingga dengan adanya pembinaan tersebut guru-guru semakin lebih kompeten dalam menyusun administrasi pembelajarannya. Jadi dengan bimbingan berkelanjutan, training, dan on the job training, Peraturan Menteri Pendidikan dan Kebudayaan Nomor 103 Tahun 2014 Terhadap Rencana Pembelajaran Guru dapat terimplementasikan dengan baik. Dengan demikian diharapkan guru yang menjadi ujung tombak dalam mencerdaskan kehidupan anak-anak bangsa di Negara Kesatuan Republik Indonesia tercinta ini mempunyai kemampuan yang berkualitas.

\section{Penutup}

Bimbingan berkelanjutan, training, dan on the job training dapat meningkatkan motivasi guru dalam menyusun RPP dengan lengkap. Guru 45 IJurnal Vijjacariya Vol.3 Nomor 1 Tahun 2016 
menunjukkan keseriusan dalam memahami dan menyusun RPP apalagi setelah mendapatkan bimbingan pengembangan/penyusunan RPP, training, dan on the job training. Bimbingan berkelanjutan, training, dan on the job training dapat meningkatkan kompetensi guru dalam menyusun RPP. Penulis menyampaikan beberapa saran sebagai berikut: (1) motivasi yang sudah tertanam khususnya dalam penyusunan RPP hendaknya terus dipertahankan dan ditingkatkan/ dikembangkan; (2) RPP yang disusun/dibuat hendaknya mengandung komponen-komponen RPP secara lengkap dan baik karena RPP merupakan acuan/pedoman dalam melaksanakan pembelajaran; (3) dokumen RPP hendaknya dibuat minimal dua rangkap, satu untuk arsip sekolah dan satunya lagi untuk pegangan guru dalam melaksanakan proses pembelajaran.

\section{Daftar Pustaka}

Daradjat, Zakiyah. 1980. Kepribadian Guru. Jakarta: Bulan Bintang.

Dewi, Kurniawati Eni . 2009. Pengembangan Bahan Ajar Bahasa Dan Sastra Indonesia Dengan Pendekatan Tematis. Tesis. Surakarta: Program Pascasarjana Universitas Sebelas Maret.

Depdiknas. 2003. UU RI No. 20 Tahun 2003 tentang Sistem Pendidikan Nasional. Jakarta: Depdiknas.

2004. Standar Kompetensi Guru Sekolah Dasar. Jakarta: Depdiknas.

2005. UU RI No. 14 Tahun 2005 tentang Guru dan Dosen. Jakarta: Depdiknas.

2005. Standar Nasional Pendidikan. Jakarta: Depdiknas.

2007. Permendiknas RI No. 41 Tahun 2007a tentang Standar Proses. Jakarta: Depdiknas.

2008. Alat Penilaian Kemampuan Guru. Jakarta: Depdiknas.

Fatihah, RM . 2008. Pengertian konseling (Http: //eko13.wordpress.com, diakses 19 Maret 2009).

Imron, Ali. 2000. Pembinaan Guru Di Indonesia. Malang: Pustaka Jaya.

Pidarta, Made . 1992. Pemikiran Tentang Supervisi Pendidikan. Jakarta: Bumi Aksara.

Sudjana, Nana. 2009. Standar Kompetensi Pengawas Dimensi dan Indikator. Jakarta : Binamitra Publishing.

Suparlan. 2005. Menjadi Guru Efektif. Yogyakarta: Hikayat Publishing. 2006. Guru Sebagai Profesi. Yogyakarta: Hikayat Publishing.

Tim Redaksi Kamus Besar Bahasa Indonesia. Edisi kedua 